\title{
Effect of storage conditions on Moringa oleifera Lam. seed oil: Biodiesel feedstock quality
}

Helene Fotouo-M.*, Elsa S. du Toit, and Petrus J. Robbertse

Department of Plant Production and Soil Science, University of Pretoria, 0002, South Africa

* Corresponding author: Helene Fotouo, Department of Plant Production and Soil Science, University of Pretoria, 0002, South Africa; E-mail: helene.fotouo@up.ac.za

\section{Highlights}

- Oil content was unchanged at 12 months but decreased significantly at 24 months.

- FFA increased significantly after 12 months and onwards at all storage conditions.

- The density of Moringa seed oil remained unchanged throughout storage.

- The viscosity of oil was mostly unchanged at 24 months except for few conditions.

- Seed moisture content and storage temperature can influence the quality biodiesel.

\section{INTRODUCTION}

Moringa seed oil is known as Ben oil. It is considered as a great natural cosmetic emollient based on its tactile property and nearly total absence of colour and odour (Ayerza, 2011). Moringa seed oil can also be used as cooking oil and industrially as a fine machine lubricant (Rahman et al., 2009). Recently, research by several authors illustrated the potential use of ben oil for biodiesel production (Rashid et al., 2008). Moringa oil is said to be highly resistant to oxidation rancification (Tsaknis et al., 1999). Preserving properties of seeds and maintaining the quality of extractable compounds are among the major challenges that have been faced by food industries for many years and recently by biodiesel industries. 
Environmental factors such as temperature, light, as well as sowing date and irrigation regime can affect the composition of vegetable oils and therefore their physical and chemical characteristics. The quality of crude oil is also influenced by the storage conditions of seeds before industrial extraction (Martini \& Anon, 2005). Storage is done to preserve harvesting quality, but not to improve it (Sisman \& Delibas, 2004). The storage problem is exacerbated by storage conditions such as exposure to air, light, temperature and moisture. Oil quality is directly related to the physiological condition of the seeds from which it is extracted (Terigar et al., 2010). Oil extracted from damaged and deteriorated seed can develop volatile acids, high acidity and low stability.

A reduction in oil content of damaged seed was reported by Santhya et al. (2008) who identified hydrolysis and oxidation to be the reasons for the decrease in oil quantity and quality in stored seed. Hydrolysis occurs because of moisture as triglycerides are decomposed and fatty acids are released. Many vegetable oils possess a significant amount of fatty acids with double or triple bonds, rendering oxidative stability a concern, especially when storing oil over an extended period of time (Knothe, 2007).

Several studies have highlighted the effect of environmental conditions on stored vegetable oils. Many authors (Sisman \& Delibas, 2004; Sisman, 2005 and Martini \& Anon, 2005) have reported that an increase in temperature and humidity causes oil degradation and an increase free fatty acids in sunflower oil. This was later confirmed by Tassan et al. (2011) and Abdellah and Ahmed Ishag (2012) who observed significant changes in physical and chemical characteristics of sunflower oil, both in stored oil and in fresh oil extracted from stored seeds, irrespective of the extraction method. Similar observations have been reported 
by Rao (2008) with stored Jatropha seed oil and by Vujasinovic et al. (2010) with pumpkin seed oil.

Globally, biodiesel quality is being standardized to obtain an end product of good quality, to ensure better criteria of storage, and to successfully commercialize (Atabani et al., 2012; Kandil et al., 2013; Othman \& Ngassapa, 2010). Since biodiesel is produced from feedstocks of various origins and qualities, it is important to standardize fuel quality to guarantee an engine performance without hitches. Currently, the properties and qualities of biodiesel must conform to the international biodiesel standard specification. The main specifications are American Standards for Testing Materials (ASTM 6751-3) or the European Union Standard for biodiesel fuel (EN 14214) (Atadashi et al., 2010). Other standards are available globally such as in Germany (DIN 51606) and South Africa (SANS 1935) (Wilson et al., 2005). The effect of storage conditions on moringa seed oil is not known. The aim of this study is therefore to investigate the effect of various storage conditions and - duration on M. oleifera seed oil quantity and quality as a potential source of biodiesel.

\section{Material and methods}

Seeds from pods harvested in an orchard of the Hatfield Experimental Farm of the University of Pretoria $\left(25^{\circ} 45 \mathrm{~S}, 28^{\circ} 16 \mathrm{E}\right)$ from June to October 2012 were used. The experimental design was as follows:

\subsection{Experimental procedure}

The effect of storage conditions and storage period was assessed by a two-fold experiment:

1) Oil was extracted from freshly harvested seeds and samples of $55 \mathrm{ml}$ were stored in triplicates at ambient room temperature $\left(15-25^{\circ} \mathrm{C}\right)$ in dark (to prevent light) glass bottles. 
Oil quality was assessed at the end of each of three storage periods, six, 12 and 24 months. This treatment will be referred as "stored oil" in the rest of the paper.

2) Seeds were stored following a factorial $2 \times 4 \times 3$ experiment with two types of storage containers (open paper bags $(\mathrm{P})$ and sealed aluminium bags $(\mathrm{A})$, four temperatures $(-19$, 4, 20 and $30^{\circ} \mathrm{C}$ ) and three storage periods (six (6), 12, and 24 months). Each treatment was stored in triplicate, with each replicate consisting of about $220 \mathrm{~g}$ of seeds. Additional seed bags were stored in order to limit experimental failure. At the end of each storage period, oil was extracted from stored seed and analysed together with the pre-stored extracted oil.

\subsection{Determination of oil content}

Oil content was determined by AOAC standards method (AOAC, 2000). The de-hulled seed were ground into a fine paste using a coffee grinder. Oil was extracted from two grams of seed powder with hexane at $40-60^{\circ} \mathrm{C}$ for $8 \mathrm{~h}$ using a Soxhlet extractor fitted with $500 \mathrm{ml}$ round-bottomed flask and condenser. This was done three times and the oil content was expressed on a dry matter basis.

\subsection{Determination of moringa seed oil properties}

\subsubsection{Oil extraction}

Before extraction, the seed was dehulled in order to maximize the amount of oil extract.

Firstly, seeds were pressed using a screw press machine (Piteba 2012, Netherlands) at the Hatfield Experimental Farm of the University of Pretoria (average annual temperatures of $15^{\circ} \mathrm{C}$ minimum and $25^{\circ} \mathrm{C}$ maximum). The screw press machine used is a small home oils expeller that is operated manually. Oil is extracted by exposing the seeds to very high 
pressure in the press cage when turning the crank. Heat from a small burner was sometimes used to accelerate the extraction but the temperature was monitored and maintained below $50^{\circ} \mathrm{C}$ to prevent oil deterioration. Secondly, the pressed cake obtained from the press machine was ground with a coffee grinder to a fine paste and the remaining oil was then extracted with a Soxhlet extractor; the solvent was distilled off to recover the oil. Residual solvent was removed by heating the flask to $40-50^{\circ} \mathrm{C}$ for $60 \mathrm{~min}$. The oil was poured into a bottle and then kept in the dark at $4{ }^{\circ} \mathrm{C}$ until the analysis was done.

2.3.2. Determination of Free fatty acid, density and viscosity of moringa seed oil Following oil extraction, the free fatty acid content, density and viscosity were determined. The pressed oil was used for Viscosity and density analysis. The remaining pressed oil was mixed with the solvent extracted oil and used for free fatty acid analysis.

\subsubsection{Free fatty acid content}

The free fatty acid was determined by means of the AOAC method 940.28 (titration method) (AOAC, 2000). Samples were dissolved in alcohol and neutralised with phenolphthalein. Sodium hydroxide $(0.25 \mathrm{M})$ was used for titration. The volume of sodium hydroxide used in titration was reported as a percentage of free fatty acids expressed as oleic acid.

\subsubsection{Viscosity and density}

A Stabinger viscometer (Model SVM 3000) was used to establish both the viscosity and density according to the ASTM method D7042-11 (ASTM, 2011). The Stabinger viscometer uses a rotational coaxial cylinder measuring system. The test specimen is introduced into measuring cells, which are at a closely controlled and known temperature. The dynamic viscosity is determined from the equilibrium rotational speed of the inner cylinder under the 
influence of the shear stress of the test specimen and an eddy current brake adjustment data (ASTM, 2011). The digital density analyser uses a U-shaped oscillating sample tube and a system for electronic excitation and frequency counting.

The apparatus was set at $40^{\circ} \mathrm{C}$. Five millilitres of oil sample was loaded into the syringe. The syringe was introduced into the viscometer inlet opening, two millilitres of oil was injected into the measuring cells initially and the measurement was initiated without removing the syringe. Values were recorded when the instrument had indicated that the determination was valid. Another $1 \mathrm{ml}$ was injected and the measurement repeated. This last step was repeated three times with the final value representing the average of the three readings. This procedure was repeated three times.

\subsubsection{Statistical analysis}

Statistical analysis was assayed using the Statistical Analysis System (SAS Version 14.1) program for Microsoft Windows. The Analysis of Variance (ANOVA) was performed, together with Duncan test to enable the comparison between treatment means at $p \leq 0.05$. The interaction between factors was taken into consideration.

\section{Results}

Physical and chemical characteristics of moringa oil are shown in Table 1. Most of the characteristics of oil from fresh seed are similar to those of moringa oil of various origins found in literature as shown in Table 1. 
Table 1 : Characteristics of moringa seed oil from different origins (compiled by present author adapted from $(2,4,22-24))$.

\begin{tabular}{|c|c|c|c|c|c|c|c|c|}
\hline Solvent & \multicolumn{2}{|c|}{ Cold press } & \multicolumn{4}{|c|}{ Hexane } & \multicolumn{2}{|c|}{ Hexane + screw press } \\
\hline 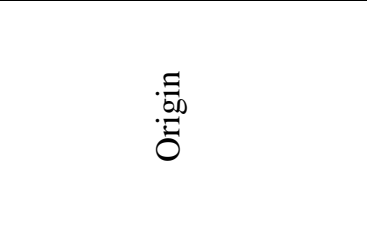 & 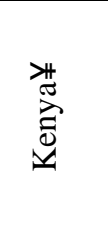 & $\begin{array}{l}\underset{\Xi}{J} \\
\underset{\Xi}{\Xi}\end{array}$ & $\begin{array}{l}\infty \\
\frac{\pi}{0} \\
\frac{0}{0} \\
\frac{\pi}{0} \\
00 \\
\tilde{D} \\
\infty\end{array}$ & 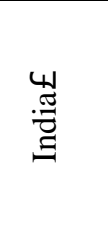 & 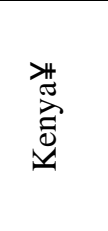 & 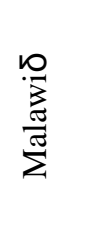 & 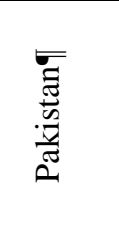 & 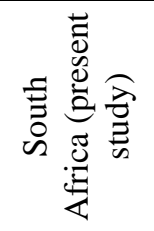 \\
\hline Oil content $(\%)$ & 25.8 & 25.1 & 37 & 38.3 & 35.7 & 35.3 & 36.2 & 38.87 \\
\hline $\begin{array}{c}\text { Density }\left(24^{\circ} \mathrm{C}\right) \\
(\mathrm{mg} / \mathrm{ml})\end{array}$ & $0.903^{\prime}$ & 0.899 & 0.898 & 0.909 & 0.881 & 0.888 & 0.904 & 0.8993 \\
\hline Viscosity $(\mathrm{mPa} \cdot \mathrm{s})$ & 103 & 88 & 56.5 & 45.1 & 57.0 & 62.0 & - & 40.51933 \\
\hline $\begin{array}{c}\text { Free fatty acid (FFA) } \\
(\% \text { oleic acid equivalent) }\end{array}$ & 1.01 & 1.94 & 0.73 & 1.12 & 0.85 & 0.82 & 0.50 & 1.75 \\
\hline $\begin{array}{c}\text { Iodine value } \\
\text { (g of Lper } 100 \mathrm{~g} \text { oil) }\end{array}$ & 66.81 & 65.73 & 68.9 & 65.6 & 66.8 & 65.7 & 68.7 & 66.43 \\
\hline Induction time $(\mathrm{h})$ & 34.1 & 28.2 & - & 31.7 & 36.8 & - & 9.94 & 26.86 \\
\hline
\end{tabular}

$£$ India (Lalas and Tsaknis, 2002), ¥ (Tsaknis et al., 1999), $\delta$ (Tsaknis et al., 1998), ๆ (Anwar and Rashid, 2007), § (Rahman et al., 2009).

\subsection{Oil content}

Moringa oil content was found to be $37-40 \%$ at harvest. The seed oil content decreased slightly after 6 months of storage, irrespective of the storage packaging type and at all four temperatures (Fig. 1). After storage for 12 months the value remained almost unchanged except for seed stored at $20^{\circ} \mathrm{C}$ and $30^{\circ} \mathrm{C}$ in aluminium bags where it decreased further (Fig. 1), although the decrease was still not statistically significant. After 24 months of storage an interaction was found between packaging $\mathrm{x}$ temperature (Table 2$)$ and a significant $(\mathrm{p}<0.05)$ difference was also found between storage periods (Table 3). The oil content of seed stored at $-19^{\circ}, 20^{\circ} \mathrm{Cand} 30^{\circ} \mathrm{C}$ in paper bags did not decrease significantly, whereas oil content for seed stored at $4^{\circ} \mathrm{C}$ decreased significantly. The oil content of seed stored in aluminium bags at $-19^{\circ}$ and $4^{\circ} \mathrm{C}$ was not significantly different to that of the control, while at $20^{\circ}$ and $30^{\circ} \mathrm{C}$ it was significantly lower with that of $30^{\circ} \mathrm{C}$ having the lowest value of all treatments. 


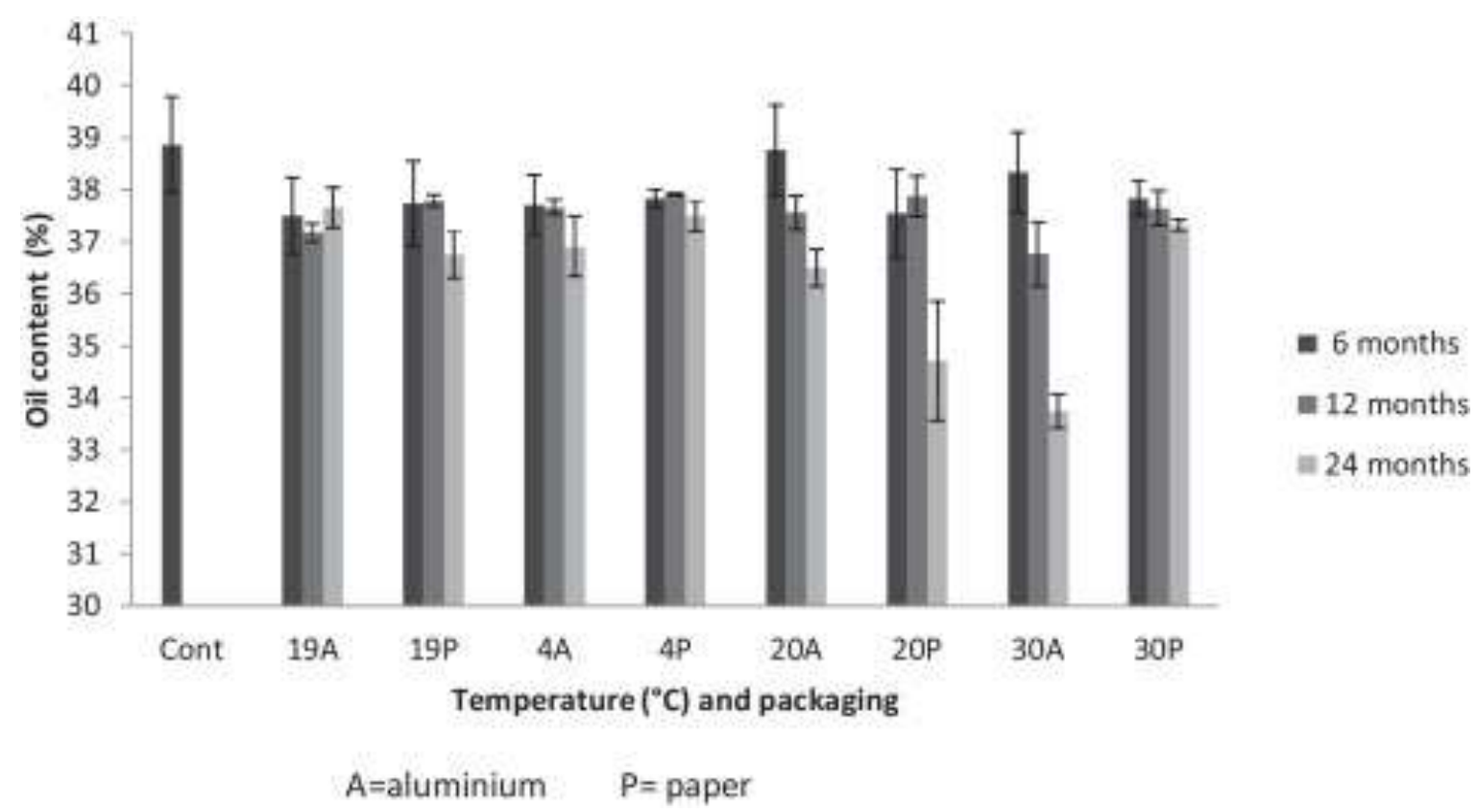

Figure 1: Oil content of moringa seed stored in aluminium and paper bags at $-19^{\circ}, 4^{\circ}, 20^{\circ}$ and $30^{\circ} \mathrm{C}$ for 6,12 and 24 months.

Table 2 : Temperature and packaging interaction on oil content of moringa seed stored at $-19^{\circ}, 4^{\circ}, 20^{\circ}$ and $30^{\circ}$ C for 24 months of storage.

\begin{tabular}{ccl}
\hline Packaging & Temperature $\left({ }^{\circ} \mathrm{C}\right)$ & Oil content $(\%)$ \\
\hline Control & $\left(15-25^{\circ} \mathrm{C}\right)$ & $38.87^{\mathrm{a}}$ \\
\hline & -19 & $37.42^{\mathrm{abc}}$ \\
Aluminium & 4 & $37.89^{\mathrm{ab}}$ \\
& 20 & $35.92^{\mathrm{c}}$ \\
& 30 & $37.597^{\mathrm{ab}}$ \\
\hline \multirow{2}{*}{ Paper } & -19 & $37.22^{\mathrm{bc}}$ \\
& 4 & $36.79^{\mathrm{bc}}$ \\
& 20 & $37.58^{\mathrm{ab}}$ \\
& 30 & $37.09^{\mathrm{bc}}$ \\
\hline
\end{tabular}

Means with the same letter are not statistically different $(\mathrm{p}<0.05)$ according to Duncan test.

Table 3 : Main effect of storage period on oil content of moringa seed at 24 months.

\begin{tabular}{cc}
\hline Storage period (months) & Oil content $(\%)$ \\
\hline Control & $38.87^{\mathrm{a}}$ \\
6 & $37.608^{\mathrm{ab}}$ \\
12 & $37.326^{\mathrm{ab}}$ \\
24 & $36.588^{\mathrm{b}}$
\end{tabular}

Means with the same letter are not statistically different $(\mathrm{p}<0.05)$ Means with the same letter are not statistically different $(\mathrm{p}<0.05)$ according to Duncan test. 


\subsection{Free fatty acid content (FFA)}

The increase in free fatty acids (FFA) in oil is an indication of deterioration. The initial FFA percentage of oil extracted from seed from the control treatment was $1.7 \%$. After six months of storage, the FFA of oil from seed in both packaging types and at all four temperatures as well as the stored oil remained unchanged, but increased significantly after 12 months of

Table 4 : Interaction between packaging, temperature and storage period on FFA content of oil from moringa seed stored in aluminium and paper bags at $-19^{\circ}, 4^{\circ}, 20^{\circ}$ and $30^{\circ} \mathrm{C}$ and stored at ambient temperature after 6,12 and 24 months.

\begin{tabular}{|c|c|c|c|}
\hline Packaging & Storage Period (months) & Temperature $\left({ }^{\circ} \mathrm{C}\right)$ & FFA (\% oleic acid equivalent) \\
\hline Control & & & $1.7^{\text {hgi }}$ \\
\hline \multirow{12}{*}{ Aluminium } & \multirow{4}{*}{6} & -19 & $1.58^{\text {hgi }}$ \\
\hline & & 4 & $1.67^{\text {hgi }}$ \\
\hline & & 20 & $1.52^{\mathrm{i}}$ \\
\hline & & 30 & $1.867^{\text {efghi }}$ \\
\hline & \multirow{4}{*}{12} & -19 & $1.75^{\text {hgfi }}$ \\
\hline & & 4 & $1.88^{\text {efghi }}$ \\
\hline & & 20 & $2.16^{\text {cdef }}$ \\
\hline & & 30 & $2.45^{\mathrm{c}}$ \\
\hline & \multirow{4}{*}{24} & -19 & $1.95^{\text {defgh }}$ \\
\hline & & 4 & $2.176^{\text {cde }}$ \\
\hline & & 20 & $2.567^{\mathrm{bc}}$ \\
\hline & & 30 & $3.48^{\mathrm{a}}$ \\
\hline \multirow{12}{*}{ Paper } & \multirow{4}{*}{6} & -19 & $1.53^{\mathrm{i}}$ \\
\hline & & 4 & $1.58^{\mathrm{hgi}}$ \\
\hline & & 20 & $1.48^{\mathrm{i}}$ \\
\hline & & 30 & $1.625^{\mathrm{hgi}}$ \\
\hline & \multirow{4}{*}{12} & -19 & $2.25^{\text {cde }}$ \\
\hline & & 4 & $1.96^{\mathrm{defg}}$ \\
\hline & & 20 & $2.167^{\text {cde }}$ \\
\hline & & 30 & $2.267^{\text {cde }}$ \\
\hline & \multirow{4}{*}{24} & -19 & $2.35^{\mathrm{cd}}$ \\
\hline & & 4 & $2.433^{\mathrm{c}}$ \\
\hline & & 20 & $2.5^{\mathrm{c}}$ \\
\hline & & 30 & $2.567^{\mathrm{bc}}$ \\
\hline \multirow{3}{*}{$\begin{array}{l}\text { Oil stored in } \\
\text { dark bottle }\end{array}$} & 6 & \multirow{3}{*}{ Ambient } & $1.75^{\text {hgfi }}$ \\
\hline & 12 & & $2.2^{\text {cde }}$ \\
\hline & 24 & & $2.93^{\mathrm{b}}$ \\
\hline
\end{tabular}

Means with the same letter are not statistically different $(\mathrm{p}<0.05)$ according to Duncan test. 
storage (Table 4). Oil from seeds stored at $30^{\circ} \mathrm{C}$ had the highest FFA percentage followed by the stored oil (Ambient). After 24 months of storage an interaction was found between the effects of packaging types, temperature and storage period (Table 4). The highest free fatty acid content was recorded in oil from seed stored in aluminium bags at $30^{\circ} \mathrm{C}$ and that of the stored oil. The lowest FFA was recorded in oil from seed stored at $-19^{\circ} \mathrm{C}$ in aluminium bags.

\subsection{Viscosity and density}

The initial density and viscosity of the oil at harvest was $0.899 \mathrm{~g} / \mathrm{ml}$ and $39.85 \mathrm{~mm}^{2} / \mathrm{s}$ respectively and no significant difference was found between treatments until 12 months of storage. The density did not change even after 24 months of storage under various conditions (Fig. 2). At 24 months of storage, however, an interaction was found between packaging and

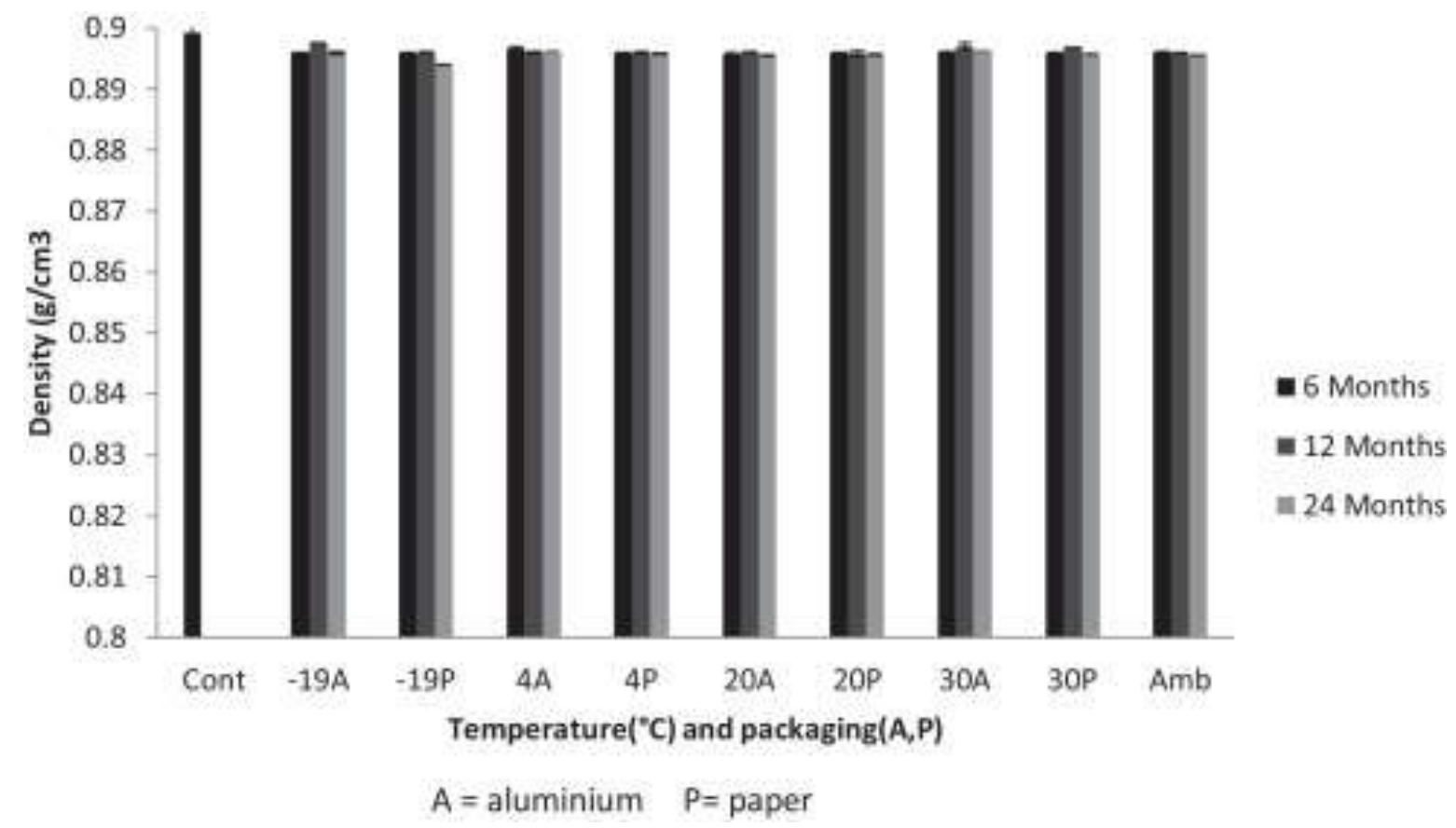

Figure 2: Density of moringa seed oil stored in aluminium and paper bags at $-19^{\circ}, 4^{\circ}, 20^{\circ}$ and $30^{\circ} \mathrm{C}$ for 6,12 and 24 months. 
Table 5 : Interaction of temperature and packaging on viscosity of oil from moringa seed stored at $-19^{\circ}, 4^{\circ}, 20^{\circ}$ and $30^{\circ} \mathrm{C}$ and oil stored at ambient temperature for 24 months of storage.

\begin{tabular}{ccl}
\hline Packaging & Temperature $\left({ }^{\circ} \mathrm{C}\right)$ & Viscosity $\left(\mathrm{mm}^{2} / \mathrm{s}\right)$ \\
\hline Control & & $39.85^{\mathrm{a}}$ \\
\hline & -19 & $39.2^{\mathrm{a}}$ \\
Aluminium & 4 & $38.85^{\mathrm{ab}}$ \\
& 20 & $38.75^{\mathrm{ab}}$ \\
& 30 & $38.97^{\mathrm{ab}}$ \\
\hline \multirow{2}{*}{ Paper } & -19 & $37.88^{\mathrm{b}}$ \\
& 4 & $38.98^{\mathrm{ab}}$ \\
& 20 & $38.69^{\mathrm{ab}}$ \\
\hline Oil stored in dark bottle & 30 & $38.86^{\mathrm{ab}}$ \\
\hline
\end{tabular}

Means with the same letter are not statistically different $(\mathrm{p}<0.05)$ according to Duncan test.

temperature (Table 5). The lowest value was recorded in oil extracted from seed stored in paper bags at $-19^{\circ} \mathrm{C}$. Oil extracted from seed stored under other conditions was lower but not significantly different from the control. An interaction was also recorded between storage period and temperature (Table 6). The lowest viscosity was recorded for oil extracted from seed stored at $-19^{\circ} \mathrm{C}$, followed by that of the stored oil after 24 months of storage. The viscosity of extracted oil stored at $4^{\circ}, 20^{\circ}$ and $30^{\circ} \mathrm{C}$ were not significantly different from the control.

Table 6 : Interaction between storage period and temperature affecting the viscosity of oil from moringa seed stored at $-19^{\circ}, 4^{\circ}, 20^{\circ}$ and $30^{\circ} \mathrm{C}$ and oil stored at ambient temperature for 24 months of storage

\begin{tabular}{ccc}
\hline Storage period (Months) & Temperature $\left({ }^{\circ} \mathrm{C}\right)$ & Viscosity $\left(\mathrm{mm}^{2} / \mathrm{s}\right)$ \\
\hline Control & & $39.85^{\mathrm{a}}$ \\
\hline \multirow{2}{*}{6} & -19 & $38.92^{\mathrm{ab}}$ \\
& 4 & $39.2^{\mathrm{a}}$ \\
& 20 & $38.98^{\mathrm{ab}}$ \\
& 30 & $39.02^{\mathrm{a}}$ \\
\multirow{2}{*}{12} & stored oil ( ambient) & $38.69^{\mathrm{ab}}$ \\
& -19 & $39.56^{\mathrm{a}}$ \\
& 4 & $38.78^{\mathrm{ab}}$ \\
& 20 & $38.70^{\mathrm{ab}}$ \\
& 30 & $39.32^{\mathrm{a}}$ \\
\multirow{2}{*}{24} & -19 & $38.71^{\mathrm{ab}}$ \\
& 4 & $37.49^{\mathrm{c}}$ \\
& 20 & $38.74^{\mathrm{ab}}$ \\
& 30 & $38.48^{\mathrm{ab}}$ \\
& stored oil (ambient) & $38.53^{\mathrm{ab}}$ \\
& stored oil ( ambient $)$ & $38.12^{\mathrm{bc}}$ \\
\hline
\end{tabular}

Means with the same letter are not statistically different $(\mathrm{p}<0.05)$ according to Duncan test. 


\section{DISCUSSION}

\subsection{Oil content}

Previous studies have estimated the oil content of fresh moringa seed by the solvent extraction method to be between 35-41\% (Rahman et al., 2009). The decrease in oil seed content during storage has been reported by other authors. Gupta and Rao (2008) also reported a decrease in oil content in Jatropha seed when they stored the seed at ambient temperature for just 80 days. Similar observations were made by Savić et al. (2009) when they stored rapeseed for 9 months at $10^{\circ} \mathrm{C}$, Harhar et al. (2010) with argon kernels, and by Tchiegang et al. (2005) with Ricinodendron heudelotti kernels. According to Sathya et al. (2006) the reduction of oil content in stored seed was the result of hydrolysis and oxidation. Oxidation is a multiple step process that leads to multiple products which result in oil degradation (List et al., 2005).

\subsection{Free fatty acid content (FFA)}

Seed stored in aluminium bags more or less maintained their initial moisture content throughout storage while the moisture content of seed in paper bags increased or decreased depending on the temperature and the relative humidity of the incubator. The higher increase in FFA recorded in oil from seed stored in aluminium bags at $30^{\circ} \mathrm{C}$ is as a result of high moisture content in the seed, whereas the moisture content of seed stored in the paper bags at $30^{\circ} \mathrm{C}$ decreased during storage (from $8.3 \%$ to $5 \%$ ). The difference between the FFA in oil from seed stored at $-19^{\circ} \mathrm{C}$ in aluminium bags and in paper bags can also be as the result of variation in moisture content. Although seed stored at $-19^{\circ} \mathrm{C}$ in aluminium bags also maintained their initial moisture content, the increase in FFA in the oil was prevented by the freezing temperature. The same FFA value could not be maintained for seed stored in paper bags because their moisture content had increased (above 9\%) during the storage. Overall, the 
difference observed between treatments is mainly as result of the combined effect of packaging type and temperature which affects seed moisture absorption. Lin et al. (2012) found a significant $(\mathrm{p}<0.05)$ increase in FFA with increasing seed moisture content, temperature and storage time when they stored almond seed for 500 days at $4^{\circ}, 21^{\circ}$ and $37^{\circ} \mathrm{C}$ and at $45 \%, 75 \%$ and $95 \%$ relative humidity. An increase in FFA content of oil extracted from rapeseed stored at $10^{\circ} \mathrm{C}$ for 9 months was reported by Savić et al. (2009). Similar observations were noticed by Lopez et al. (1995) when they stored unshelled walnut seeds at cold temperatures $\left(3^{\circ}, 7^{\circ}\right.$ and $\left.10^{\circ} \mathrm{C}\right)$ for 12 months, with the highest FFA recorded in seeds stored at $10^{\circ} \mathrm{C}$. The increase in FFA in stored oil is likely the result of a combination of both hydrolysis and oxidation as water content of the oil was not determined before storage. An increase of FFA in Jatropha oil stored at ambient temperature for 72 days has been reported by Gupta and Rao (2008). The quick increase in FFA at high temperature and high humidity may be due to high activity of lipases and other enzymes that hydrolyse triglycerides into free fatty acids, diglycerides and monoglycerides (Gulla \& Waghray, 2011). FFA resulting from these reactions may further be oxidized and give rise to rancidity (Lin et al., 2012).

Oil with high FFA is prone to oxidation and may lead to gum and sludge formation (Savic et al., 2009; Karmakar et al., 2010). Crude vegetable oil with high FFA content leads to soap formation and a lower yield of biodiesel (Sahoo \& Das, 2009). Thus to overcome these problems transesterification is done in a double or triple stage process depending on the amount of FFA. The higher the FFA percentage the higher the number of stage processes needed, thus increasing the production cost (Karmakar et al., 2010) as more solvent and catalyst are used. The FFA of vegetable oil used for biodiesel production must not be more than 2\% (Zhu et al., 2011; Savic et al., 2009). In this study the oil extracted from freshly harvested seed (control) had a FFA of $1.7 \%$, making it suitable as biodiesel feedstock. After 
storage, only oil from seed stored in aluminium at $-19^{\circ} \mathrm{C}$ maintained its FFA below $2 \%$ after 24 months. The FFA in oil from seeds stored at $4^{\circ} \mathrm{C}$ in both packaging types was below $2 \%$ until 12 months. Seed stored at $20^{\circ}$ and $30^{\circ} \mathrm{C}$ in both packaging types produced oil wit FFA was $2 \%$ only after 6 months of storage and increased above this value onward.

\subsection{Viscosity and density}

Viscosity and density are important fuel properties that can affect engine performance (Refaat, 2009). The injection fuel amount, injection timing and injection spray pattern are affected by these parameters. Fuel with high viscosity tends to form large droplets on injection leading to poor fuel atomization during spray. It increases engine deposit and as a result more energy is needed to pump the fuel. This problem can be intensified in cold weather (Canacki \& Sanli, 2008; Refaat, 2009). Fuel with low viscosity can also cause problems such as providing insufficient lubrication of fuel injection pumps resulting in leakage. Viscosity of any fuel is related to its chemical structure and the viscosity of the biodiesel increases as the viscosity of the feedstock increases (Dermimas, 2005). Fuel is pumped by volume, not by mass, although a denser fuel contains a greater mass in the same volume and it is less compressible (Canacki \& Sanli, 2008; Refaat, 2009). Like viscosity, the change in fuel density will influence the engine injection system and thus engine output. A decrease in viscosity as storage period increases has been reported by Nierat (2012) when he stored oil in dark glass bottles at room temperature for 13 years and assessed it on a monthly and yearly basis. Contrary to the result obtained in this study, Knothe (2007) reported an increase in viscosity after storing biodiesel for two years. An increase in viscosity during storage has been reported by many other authors (Kapilan et al., 2009; Bouais et al., 2007). Free fatty acids formed during hydrolysis and oxidation as well as double bond isomerization, saturation and high molecular weight products such as compounds like 
polymers lead to the increase of viscosity during storage. There is not clear explanation for the decrease in viscosity during storage. It is said that other than the chain length and the degree of saturation that influences oil viscosity, factors such as double bond configuration also influence viscosity with Cis configuration giving lower viscosity than Trans (Savić et al., 2009). The decrease in viscosity could be as a result of unidentified chemical changes of fatty acids.

The kinematic viscosity of biodiesel is approximately an order of magnitude (power of 10) less than of the parent oil (Ramos et al., 2009; Moser, 2009). For example, according to literature (Canackci \& Sanli, 2008; Refaat, 2009) the viscosity of the following oils are: rice bran (36.68), sesame (36), sunflower (35.84), peanut(39.6), Jatropha (33.8), cottonseed oil (33.5) and the viscosity of the derived biodiesel are respectively 4.9, 4.2, 4.43, 4.9, 4.8 and $3.75 \mathrm{~mm}^{2} / \mathrm{s}$. According to American Standards for Testing Materials and European standard requirements for biodiesel, the viscosity of biodiesel must fall between $1.9-6.0 \mathrm{~mm}^{2} / \mathrm{s}$ and 3.5 $5.0 \mathrm{~mm}^{2} / \mathrm{s}$ respectively. In the present study the viscosity of moringa oil was between 37.88 $39.85 \mathrm{~mm}^{2} / \mathrm{s}$. If the formula of "order of magnitude less than" applies and also by looking at the examples cited above, the oil used for this study falls within the requirements of both or at least one of the standards. This mean that the decrease in viscosity recorded during the storage will not have a major impact on the viscosity of biodiesel.

\section{Conclusions}

The oil content of $M$. oleifera seed did not change significantly after 12 months of storage. At 24 months, the oil content of seed stored at $4^{\circ} \mathrm{C}$ in paper bags and at $20^{\circ}$ and $30^{\circ} \mathrm{C}$ in aluminium bags were significantly lower than the control (no storage). The free fatty acid increased significantly after 12 months at all storage conditions and continued to increase above the recommended value (2\%) at 24 months for biodiesel parent oil, except for that of seed stored at $-19^{\circ} \mathrm{C}$ in aluminium bags. The decrease in oil content and increase in free fatty 
acids was probably due to of hydrolysis and oxidation processes that can be accelerated by the high moisture content in the seed. The density of moringa seed oil remained unchanged throughout storage. The viscosities of oil extracted from seed stored in paper bags at $-19^{\circ} \mathrm{C}$ and that of the oil stored at ambient temperature decreased significantly at 24 months.

However, based on available literature the average oil density of less than $2 \mathrm{~mm}^{2} / \mathrm{s}$ will not have a major effect on the final viscosity of the derived biodiesel. Moisture content, temperature and storage period at which seeds are stored can influence the quality of the derived biodiesel, but seed moisture seems to be the main factor influencing the quality of the extracted oil. Seed can be stored at any of the applied conditions for six months, but if it is stored beyond this period, the use of low temperature such as $-19^{\circ} \mathrm{C}$ and $4^{\circ} \mathrm{C}$ and the use of sealed containers such as aluminium bags are recommended. Storage of the extracted oil for more than 12 months is discouraged.

\section{Acknowledgements}

Authors thank the National Research Foundation, South Africa for the funding and the Department of Chemical Engineering of University of Pretoria for the facilities.

\section{References}

Abdelmonem, M. A., Ahmed Ishag, K.E.N., 2012. Effect of storage packaging on sunflower oil oxidative stability. Am. J. Food Technol. 7, 700-707.

American Standards for Testing Materials-ASTM D7042-11, 2011. Standard test method for dynamic viscosity and density of liquids by stabinger viscometer (and the calculation of kinematic viscosity) ASTM international, West Conshohocken, PA, 2011, www.astm.org.

Anwar, F., Ashraf, M., Bhanger, M.I., 2005. Interprovenance variation in the composition of Moringa oleifera oilseed from Pakistan. J. Am. Oil Chem. Soc. 82, 45-51.

Anwar, F., Rashid, U., 2007. Physico-chemical characteristics of Moringa oleifera seeds and seed oil from a wild provenance of Pakistan. Pakistan J. Bot. 39, 1443-1453.

Association of Official Analytical Chemists - AOAC., 2000 Official methods of analysis of AOAC International (17th ed.). Washington. 
Atabani, A.E., Silitonga, A.S., Badruddin, I.A., Mahlia, T.M.I., Masjuki, H.H., Mekhilef, S., 2012. A comprehensive review on biodiesel as an alternative energy resource and its characteristics. Renew.Sust. Energ. Rev.16, 2070- 2093.

Atadashi, I.M., Aroua M.K., Abdul Aziz, A., 2010. High quality biodiesel and its diesel engine application: a review. Renew.Sust. Energ. Rev. 14, 1999-2008.

Ayerza, R., 2011. Seed yield components, oil content, and fatty acid composition of two cultivars of moringa (Moringa oleifera Lam) growing in the arid chaco of Argentina. Ind. Crops Prod. 33, 389-394.

Bouaid, A., Martinez, M., Aracid, J., 2007. Long storage stability of biodiesel from vegetable and used frying oils. Fuel 86, 2596-2602.

Canacki, M., Sanli, H., 2008. Biodiesel production from various feedstocks and their effects on the fuel properties. J Ind. Microbiol. Biot. 35, 431-441.

Demirbas, A., 2005. Biodiesel production from vegetable oils by supercritical methanol. J Sci. Ind. Res. INDIA 64, 858-865.

Gulla, S., Waghray, K., 2011. Effect of storage on physic-chemical characteristics and fatty acid composition of selected oil blends. J Lipid Sci 3, 35-46.

Gupta, R. C, Rao, G., 2008. Effect of storage time on yield and free fatty acid (FFA) content on raw Jatropha oil. XXXII National Systems Conference, NSC December 17-19.

Harhar, H., Gharby, S., Guillaume, D., Charrouf, Z., 2010. Effect of argan kernel storage conditions on argan oil quality. Eur. J. Lipid Sci. Technol. 112, 915-920.

Kandil, A.A., Sharief, A.E., Sheteiwy, M., 2013. Effect of seed storage periods, conditions and materials on seed quality of some soybean cultivars. Int. J. Agric. Sci. 5, 339-346.

Kapilan, N., Ashok Babu, T.P., Reddy, R.P., 2009. Evaluation of Properties and Storage Stability of Madhuca indica Biodiesel. J. Oleo Sci. 58, 617-622. 
Karmakar, A., Karmakar,S., Mukherze, S., 2010. Properties of various plants and animals feedstocks for biodiesel production. Bioresource Technol. 101, 7201-7210.

Knothe, G., 2007. Some aspects of biodiesel oxidative stability. Fuel Process. Technol. 88, 669-677.

Lalas, S., Tsaknis, J., 2002. Characterisation of Moringa oleifera seed oil variety “periyakulam 1". J. Food Compos. Anal. 15, 65-77.

Lin, X, Wu, J., Zhu, R.; Chen, P., Huang, G., Li, Y., Ye, N., Huang B., Lai, Y., Zhang H., Wanyu Lin, W., Lin, J., Wang, Z., Zhang, H., Ruan R., 2010 California almond shelf life: Lipid deterioration during Storage. J. Food Sci. 77, 583-593.

List, G. R., Wang, T., Shukla, V.K.S., 2005. Storage, Handling, and Transport of Oils and Fats. Bailey's Industrial Oil and Fat Products Macmillan, London. pp146.

Lopez, A., Pique, M.T., Romero, A., Aleta, N., 1995. Influence of cold-storage conditions on the quality of unshelled walnuts. Int. J. Refrig. 8, 544-549.

Martini, S., Anon, M.S., 2005. Storage of sunflower seed: variation on the wax content of the oil. Eur. J. Lipid Sci. Technol. 107, 74-79.

Moser, B.R., 2009. Biodiesel production, properties, and feedstocks, In Vitro Cell.Dev.Biol. Plant 45, 229-266.

Nierat, T.H., 2012. Temperature and Storage Age-Dependence of Olive Oil Viscosity in Different Locations in Palestine Master thesis, Faculty of Graduate Studies, An-Najah National University - Nablus, Palestine.

Othman, O.C., Ngassapa, F.N., 2010. Physicochemical Characteristics of Some Imported Edible Vegetable Oils and Fat Marketed in Dar es Salaam. Tanzania J. Nat. Applied Sci. $1,138-137$.

Rahman, I.M., Barua, S., Nazimuddin, M., Begum, Z.A., Rahman, M.A., Hasegawa, H., 2009. Physicochemical properties of Moringa oleifera lam. Seed oil of the indigenous-cultivar of Bangladesh. J. Food Lipids 16, 540-553. 
Ramos, M.J., Fernandez, C.M., Casas, A., Rodriguez, L., Perez, A., 2009. Influence of fatty acid composition of raw materials on biodiesel properties. Bioresource Technol. 100, 261268.

Rashid, U., Anwar, F., Moser, B.R., Knothe, G., 2008. Moringa oleifera oil: A possible source of biodiesel. Bioresource Technol. 99, 8175-8179.

Refaat, A., 2009. Correlation between the chemical structure of biodiesel and its physical properties. Int. J. Environ. Sci. Technol. 6, 677-694.

Sahoo, P.K., Das, L.M., 2009. Process optimization for biodiesel production from Jatropha, Karanja and polanga oils. Fuel 88, 1588-1594.

Santhya, G., Jayas, D.S., White, N.D.G., 2006. Effect of storage conditions on deterioration of rye and canola. The Canadian society for engineering in agricultural, food, environmental and biological systems:CSBE/SGGAB 2006 Annual conferences, Edmonton, albertia .

Savić, T.B., Krička, T., Voća, N., Jurišić, V., Matin, A., 2009. Effect of Storage Temperature on Rapeseed Quality. Agric. Consp. Sci. 74, 143-147.

Sisman, B., Delibas, L., 2004. Storing sunflower seeds and quality losses during storage. $J$. Cent. Eur. Agric. 4, 239-250.

Sisman, C., 2005. Quality losses in temporary sunflower stores and influences of storage conditions on quality losses during storage. J. Cent. Eur. Agric. 6, 143-150.

Tasan, M., Gecgel, U., Demirci, M., 2011. Effects of storage and industrial oilseed extraction methods on the quality and stability characteristics of crude sunflower oil (Helianthus annuus L.).Grasas y aceites 62, 389-398.

Tchiegang, C., Aboubakar Dandjouna, A.K., Kapseu, C., Parmentier, M., 2005. Optimisation de l'extraction de l'huile par presage des amandes de Ricinodendron heudelotii PirreesPax. . Food Engeneer. 68, 79-87. 
Terigar, B.G., Balasubramanian, S., Boldor, D, 2010. Effect of storage conditions on the oil quality of Chinese tallow tree seeds. J. Am. Oil Chem . Soc. 87, 573- 582.

Tsaknins, J., Lalas, S., Gergis, V., Dourtoglou, V., Spiliotis, V., 1999. Characterization of Moringa oleifera Variety Mbololo seed oil of Kenya. J. Agric. Food Sc. 47, 4495-4499.

Tsaknis, J., Lalas, S., Gergis, V., Spiliotis, V., 1998. A total characterisation of Moringa oleifera Malawi seed oil. Riv. Ital. Sost. Gras. 75, 21-27.

Vujasinovic, V., Djillas, S., Dimic, E. Ranko, R.T., 2010. Shelf life of cold-pressed pumpkin (Cucurbitapepo L.) seed oil obtained with a screw press. J. Am. Oil Chem . 87, 14971505.

Wilson, S.C., Matthews, M., Austin, G., Von Blottnitz, H., 2005. Review of the Status of Biodiesel Related Activities in South Africa. Report for the City of Cape Town, South Africa. Pp 76.

Zhu, Y., Xu, J., Mortimer, P.E., 2011. The influence of seed and oil storage on the acid levels of rubber seed oil, derived from Hevea Brasiliensis grown in Xishuanghanna, China. Energy 36, 5403-5408. 